\title{
Comparison the effects of using different organic acids on gelatin extracted from cultured sea bream (Sparus aurata) scales
}

\section{Farklı organik asittlerin kullanımının kültüre edilmiş çipura (Sparus aurata) pullarından elde edilen jelatin üzerine etkilerinin karşılaştırılması}

\author{
Hülya Kalkan ${ }^{1}$ (D) Mehmet Tolga Dinçer ${ }^{1^{*}}$ \\ 1 Department of Fishery and Processing Technology, Faculty of Fisheries, Ege University, Izmir, Turkey \\ *Corresponding author: tolga.dincer@ege.edu.tr
}

How to cite this paper:

Kalkan, H. \& Dinçer M.T. (2018). Comparison the effects of using different organic acids on gelatin extracted from cultured sea bream (Sparus aurata) scales. Ege Journal of Fisheries and Aquatic Sciences, 35(3), 311-317. DOI:10.12714/egejfas.2018.35.3.11

\begin{abstract}
In the current study two different types of organic acids were used in gelatin extraction. The scales of gilthead seabream (Sparus aurata) were used as a source of gelatin. Also the effects on quality and gelling properties of used organic acids were investigated. Due to the determined gel strength values, high quality gelatins were produced in both groups with good functional properties. Total yield of the obtained products was found to be $31.10 \%$ (acetic acid), and $31.19 \%$ (propionic acid). According to the results, scale gelatin recovered by using acetic acid was found more suitable for industry with its $8.9^{\circ} \mathrm{C}$ gelling point. Foam formation ability of acetic acid group was determined as 2.8 where the value of propionic was 3.0 . Organic acids difference did not effect the colour of the product, both groups determined colourless and transparent. Result of the study showed that recovered collogen from gilthead sea bream scales have the potential to be an alternative source of gelatin with the determined functional properties.
\end{abstract}

Keywords: Fish scales, collagen, gelatin, bloom value, viscosity,

Öz: Yapılan çalışmada jelatin ekstraksiyonu için iki farklı organic asit kullanıımıştı. Çupra (Sparus aurata) balıklarının pulları gelatin kaynağı olarak kullanıımıştır Kullanılan organik asittlerin kalite ve jelleşme özellikleri üzerine etkileri incelenmiştir. Üretilen jelatinlerin jel dayanım değerlerine, iyi fonksiyonel özelliklere sahip ürünler olduğuna ve her iki grupta da yüksek kalitede jelatinlerin elde edildiği belirtilmiştir. Elde edilen toplam verim sırası ile $\% 31,10$ (asetik asit), ve $\% 31,19$ (propiyonik asit) olarak tespit edilmiştir. Sonuçlar doğrultusunda, asetik asit kullanılarak elde edilen jelatinin jelleşme noktası $8,9^{\circ} \mathrm{C}$ değeri ile endüstri açısından daha uygun olduğu görülmüștür. Köpük oluşum kabiliyeti değerleri asetik asit uygulaması için 2,8 ve propiyonik asit uygulama grubu için 3,0 olarak tespit edilmiștir. Farklı organic asit kullanımı renk değerlerinde bir farka neden olmamış, tüm gruplarda renksiz ve transparan ürün eldesi görülmüştür.

Anahtar kelimeler: Balık pulu, kolajen, jelatin, bloom değeri, viskozite

\section{INTRODUCTION}

Gelatin has a real wide range of applications in many industries; food, pharmaceutical and photographic industries can be some examples to identify its range. Although gelatins from beef and pork have been extensively researched, fewer studies have been published on the extraction procedures and functional properties of gelatin from cold blooded animals like fish (Norland, 1990; Osborne et al., 1990; Leuenberger, 1991; Grossman and Bergman, 1992; Kim and Cho, 1996; Gudmundsson and Hafsteinsson, 1997; Karim and Bhat, 2009). Just $1.5 \%$ of total gelatin was obtained from fish skin and scales in the World (Arnesen and Gildberg, 2002).

To convert the insoluble natural collagen to gelatin, a process is required to break non-covalent bonds to manipulate the protein structure so that cleavage and cleavage of intramolecular and intermolecular bonds leading to sufficient collagen solubility is necessary (Stainsby, 1987; GómezGuillén and Montero, 2001). While obtaining gelatin from collagen reasonable acid treatment should be enough to effect solubilization (Norland, 1990). The type of organic acid used naturally influences the functional properties of the gelatin. The type A gelatin can be identified with its isoelectric point for this determination $\mathrm{pH}$ value (between $\mathrm{pH} 6$ and 9) can act a key role and this type of gelatins are suitable for food industry (Stainsby, 1987). Thus, the quality of food grade gelatins is largely dependent on their viscometric properties (especially the gel strength). Neverthless, other properties are also important like color, transparency, flavor and easy dissolution in quality. Most of the mentioned study on gelatin was obtained from fish skins. However, there is little information about gelatin recovery from farmed fish scales (Dincer et al., 2015). 
49000 tons of scale raw material can be obtained annualy and from the fish de-scaling processing in seafood processing sector. Fish scales contain connective tissue protein, collagen and its structure almost covered with calcium salts. The range of protein can be changed $41 \%$ to $84 \%$ but the remaining was the combination of calcium phosphate and calcium carbonate (Sankar et al., 2008). Sea bass scale contain; 40-45\% moisture, 0. 10-0. $20 \%$ fat and $27-30 \%$ ash on its chemical structure (Dincer et al., 2013). Of course these values changes depending on species and the size. As mentioned before reports can be seen about collagen from skin of marine organisms but a few studies on fish scales can be seen like Kimura et al., (1991), Nagai et al., (2004), Dincer et al., (2016). In the study of Kimura et al., (1991) collagen was recovered from the carp scales with using $0.5 \mathrm{~m}$ acetic acid with the yield $7 \%$ on dry weight basis. Nomura et al., (1996) reported in their study that with using sardine scale collagen was recovered by different solvent systems. However, there is little scientific information on effects of used organic acids on gelatin obtained from collagens of fish scale.

In the current study, functional differences of (foam formation capacity and foam stability, viscosity and gelling temperature, colour, gel strength and texture profile) gelatins obtained by different organic acid extraction (acetic acid and propionic acid) solutions were studied.

\section{MATERIALS AND METHODS}

\section{Raw material}

Gilthead seabream (Sparus aurata) with in weight of 400 $600 \mathrm{~g}$ were selected in the commercial company in Izmir, Turkey. The scales were removed by an automatic scale remover (AGK Nr. 300 scaling machine, AGK Kronawitter $\mathrm{GmbH}$, Wallersdorf, Germany) and a total of $3.5 \mathrm{~kg}$ scales were transported to the laboratory packaged inside of polyethylene bags. Scales were washed and dried by using circulating air for two days. For each group, 1200 grams of scales were taken for collagen extraction and gelatin recovery.

\section{Gelatin extraction}

By removing non - collagen proteins, lipids and mineral contents, Type 1 collagen proteins was obtained from the scales. Two productions were done using $1200 \mathrm{~g}$ of dried scales to conduct research with Group A (acetic acid) and Group B (propionic acid). Same extraction procedure was followed for collagen extraction up to the end of demineralization stage. Acetic acid and propionic acid solutions were used in hydrolization stage. Used extraction steps and gelatin production wererealized by using the method of Dincer et al., (2015).

At the hydrolization step, scales were soaked in $0.05 \mathrm{M}$ acetic acid (Group A) and 0. $05 \mathrm{M}$ propionic acid (Group B) solutions for $3 \mathrm{~h}$. Then filtering was realized and $1 / 3(\mathrm{w} / \mathrm{v})$ water was filled in to the tray kept in an oven which was set at $60^{\circ} \mathrm{C}$ (overnight). Next morning solution was carried to plastic trays and dried at room temperature by using air conditioner (which was set on $18^{\circ} \mathrm{C}$ with the flow temperature $10 \pm 2{ }^{\circ} \mathrm{C}$ ). The dried thin films were grounded using a powder mill.

\section{Proximate composition and yield value}

AOAC, (2000) methods were used to determine the moisture (934. 01) ash content (942. 01) crude protein (954.01) and crude fat contents (991. 36) of seabream scales and gelatin. Carbohydrate content was determined by using Merril and Watt (1993) method by substracting technique.. The yield of the gelatin production was calculated by using the formula; dry weight gelatin/dry weight fish scale $\times 100$.

\section{Foam formation capacity and foam stability}

Foam formation capacity and foam stability were measured using a partially modified method of Sathe et al., (1982). $5 \mathrm{~g}$ gelatin samples were placed in $50 \mathrm{ml}$ distilled water and left to swell. The sample solution dissolved at $60^{\circ} \mathrm{C}$ and foam was prepared by homogenizing at $10.000 \mathrm{rpm}$ for $5 \mathrm{~min}$ (Yellow line model homogenizer, Germany). The homogenized solution was poured into $250 \mathrm{ml}$ mess flask. The foam formation ability was calculated as the volume ratio of foam liquid and foam stability calculated as the ratio of the initial volume of foam to the volume of foam after $30 \mathrm{~min}$

\section{Colour measurements}

Colour measurements were taken using method of Dincer et al., (2016). $6.67 \%$ (w/v) gel blocks were used to determine the colour values. This method was modified from the method of Scubring (2003). Before measuring each lot, the colorimeter was calibrated against a white standard (LZM 229). Samples were weighed into the bloom bottles and dissolved in distilled water to a final concentration of $6.67 \%$ (w/v). Dissolved gelatin content was transferred to a plastic container box and then placed in refrigerator for 16 hours at $5^{\circ} \mathrm{C}$. The gel blocks obtained had same smooth surface and thickness. Preliminary measurements were taken from the surface of calibration kits to record the blind. Then gel blocks were put into the calibration kits for measurements. Due to its transparent nature, measurements were taken on standard calibration kits (Tile white and Tile black). And after calculations, reference blind values were subtracted from the taken value from gel blocks.

Used calibration kit were LZM 256- Tile white $(x=14.8$, $Y=21.2$., $Z=13.9)$ and Tile Black ( $x=14.5, Y=20.8, Z=15.0)$. Using this technique, constancy was performed in measurement. In the CIE Lab system, $L^{*}$ denotes lightness on a 0 to 100 scale from black to white; $a^{*}$ denotes $(+)$ red or $(-)$ green; and $b^{*}$ denotes $(+)$ yellow or $(-)$ blue.

\section{Determination of gel strength}

Standart method of GMIA, (2013) was used to determine the gel strength values of produced gelatins. Dried gelatin samples were put into Bloom flasks $(6.67 \%$ (w / v) and dissolved in distilled water $(100 \mathrm{ml})$ with using hot plate at 55 ${ }^{\circ} \mathrm{C}$. Then kept in to refrigerator for 16 hours at $5^{\circ} \mathrm{C}$ to perform the gells. The gel strength measurement was realized via using a TAXT Plus (Stable Micro Systems, Godalming, UK) with a 
load cell of $25 \mathrm{~kg}$ (with using GL 4 / P 05S probe). The maximum force (in grams) was recorded when the probe penetrated $4 \mathrm{~mm}$ into the surface of the gelatin.

\section{Determination of viscosity and gelling temperature}

Viscosity measurement was done $(6.67 \% \mathrm{w} / \mathrm{v})$ at $55^{\circ} \mathrm{C}$ gel solution via using a viscometer (Brookfield DV + II Pro model, Middleboro, USA) with using $\mathrm{HA}-4$ spindle in $60 \mathrm{rpm}\left(25^{\circ} \mathrm{C}\right.$, $100 \mathrm{ml}$ solution). In addition, helipad stand equipment was used to get the rheological values in different heights of the solution solution due to the method of Zhou and Regenstein, (2004).

Gelling point (temperature) was also determined with using the same equipment and the same spidle but that time data was recorded in each minute (the test continued until the spindle stopped) while the spindle was running at $60 \mathrm{rpm}$. First data was taken from $50^{\circ} \mathrm{C}$ gel solution and continuesly software was recorded the value in each minute when the solution temperature was decreasing. In order to accelerate the cooling step and to reach $4{ }^{\circ} \mathrm{C}$ temperature, the samples flask was placed in an ice-filled chamber and sample was first cooled down to room temperature and than cooling continued until the spindle stopped. Used original method was from the study of Zhou and Regenstein, (2004) but modified to determine the gelation temperature by Dincer et al., (2016). The gelling temperature value was detected when spindle forced with maximum viscosity and the rotation of the spindle stopped.

\section{Texture profile analysis}

The measurement was made on $6.67 \%$ (w / v) gel form 6.67 grams of gelatin was dissolved in 100 water. The prepared solution was poured in a rectangular plastic container to perform a rectangular and uniform gel formation at $5^{\circ} \mathrm{C}$ for 16 hours. Gel block was cut in to $2 \mathrm{~cm} \times 2 \mathrm{~cm}$ square pieces with using a blade. Samples were compressed twice at a cross speed of $0.80 \mathrm{~mm} / \mathrm{sec}$ with using $65 \%$ compression rate. $5 \mathrm{~cm}$ diameter cylindric probe was used to perform the TPA measurement. The mechanical parametres of textural profile was evaluated by using the modified method of Yang et al., (2007).

\section{Statistical analyses}

SPSS programme (SPSS 15. 0 for Windows, SPSS Inc, Chicago, IL, USA) was used. The difference of means between groups were determined by using an Independent Sample TTest technique. And level of significance was set for $p<0.05$ in the software.

\section{RESULTS AND DISCUSSION}

\section{Yield and the proximate composition}

Scales of gilthead sea bream (Sparus aurata) proximate composition data were determined as follows; $0.10 \%$ crude fat, $41.56 \%$ moisture, $29.12 \%$ ash, $0.84 \%$ carbohydrate, and $27.14 \%$ crude protein in the scale structure. Determined values of the produced scale gelatin were (in dried form) determined as follows; in Group A 3.17\% moisture, 0.006\% ash, 96.81\% crude protein and in Group B 6.69\% moisture, 0.006\% ash, $93.30 \%$ protein, and no crude fat and carbohydrate were determined in both groups (Table 1). The yield value of gelatin was found $31.10 \%$ (Group A-373.20 g), and 31. $19 \%$ (Group B-374.28 g) respectively. As Montero and Gomez-Guillen (2000) mentioned in their study, yield value and the quality of gelatin generally depend on the extraction method of collagen. Essentially, acid treatment is mainly used and preffered for fish and fish skin; in the extraction method the collagen was first acidified for a certain period of time and then heat treatment was used to solubilize the collagen structure. Both acidity part and the heat treatment part require the monitoring process to obtain better quality of gelatin. In the current study, acidified period was fixed at 3 hours before being heated at $60^{\circ} \mathrm{C}$. The difference in chemical composition between the gelatin groups could be perceived as resulting from different organic acids used in the process. In general, the reduction of yield may cause losses of collagen extracted by leaching throughout the washing stages, or full hydrolysis of collagen may be realiyzed (Jamilah and Harvinder, 2002). In the current study, though high yield values were obtained, they still conform to the previous studies.

Muyong et al., (2004) recovered gelatin from skin of Nile perch in their study. These researchers also compared the differences of skin and gelatin chemical composition values in the mentioned study. Skin proximate composition values for protein and crude fat contents were given $78.1 \%$ and $5.6 \%$, respectively. On the other hand, when the extraction temperature was set at $50^{\circ} \mathrm{C}$, the protein, water and fat contents in the extracted gelatin from the Nile perch were determined as follows; $88.0 \%, 10.5 \%$ and $0.10 \%$, respectively. In a comparison with Muyong et al., (2004) and the current study it can be said that obtained gelatin from sea bream scales have higher protein and lower water contents.

Table 1. Chemical composition values of obtained fish scale gelatins

\begin{tabular}{lllll}
\hline Chemical composition (\%) & Protein & Moisture & Ash & Fat \\
\hline Group A & $96.81 \pm 1.05^{\mathrm{a}}$ & $3.17 \pm 0.74^{\mathrm{a}}$ & $0.0060 \pm 0.31^{\mathrm{a}}$ & $0.00 \pm 0.00^{\mathrm{a}}$ \\
Group B & $93.30 \pm 1.01^{\mathrm{b}}$ & $6.69 \pm 0.24^{\mathrm{b}}$ & $0.0063 \pm 0.00^{\mathrm{a}}$ & $0.00 \pm 0.00^{\mathrm{a}}$ \\
\hline
\end{tabular}

Data are expressed as mean \pm stdev, $(n=3)$

Different superscript letters in the same column indicate significant differences $(p<0.05)$

Group A; Sea bream scale gelatin obtained by acetic acid, Group B; Sea bream scale gelatin obtained by propionic acid. 


\section{Foam formation ability and foam stability}

Foaming formation ability is one of the important properties of gelatin. Especially for commonly used foods and food industry. Foam formation abilities of Group A and Group B gelatins are shown in Table 2. Data were given as ratio (the ratio of foam volme/liquid volume). Foam formation ability of Group A was determined as 2.8 while the value of Group B was 3.0. No statistical difference was determined between the two groups $(p>0.05)$. This implies that using different organic acids did not have effect on foam formation ability of the two groups. Similiar high results were also found in the study of Cho et al., (2004). These researchers studied the gelatin obtained from shark cartilage and compared the functional properties of obtained fish gelatin with porcine gelatin. According to their results, foam ability of shark cartialge gelatin was 2.6. In the same study, analytical grade gelatin (GA) and food additives grade(GF) of porcine gelatins were also investigated.
Determined results of foam abilities were as follows; for GA 2.8 and 2.9 for GF. When these results were compared with the findings of current study, it was found that fish scale gelatins foaming ability were found to be higher than shark cartilage gelatin (GS) and somehow of similar values with that of porcine gelatin.

Foam stability of Group A and Group B gelatins are also given in Table 2. As shown, statistical differences $(p<0.05)$ were abserved between foam stability of Group A (1.6) and Group B (2.1). Foam stability may directly effectthe aggregation of proteins (generally reduce) which the interactions between protein content and needed water for foam formation (Kinsella, 1977). The increment observed could also be assumed to result from the same reason or the acid used propionic acid. Foam stabily values found in both groups of our study were higher than the determined GA, GS, GF foam stability values of Cho et al., (2004).

Table 2. Foam ability and foam stability values of obtained fish scale gelatins

\begin{tabular}{lll}
\hline Samples & Foaming ability & Foam stability \\
\hline Group A & $2.8 \pm 0.21^{\mathrm{a}}$ & $1.6 \pm 0.19^{\mathrm{a}}$ \\
Group B & $3.0 \pm 0.22^{\mathrm{a}}$ & $2.1 \pm 0.16^{\mathrm{b}}$ \\
\hline
\end{tabular}

Data are expressed as mean \pm stdev, $(n=3)$. Different superscript letters in the same column indicate significant differences $(p<0.05)$. Group $A$; Sea bream scale gelatin obtained by acetic acid, Group B; Sea bream scale gelatin obtained by propionic acid.

\section{Viscosity and gelling temperature}

Viscosity values of Group A was determined as $20 \mathrm{Cp}$, lower than $33 \mathrm{Cp}$ value of Group B in room temperature. The gelling temperatures of the samples are given in Figure 1 and Figure 2. The plots of delta (viscosity -temperature) compared with temperature $\left({ }^{\circ} \mathrm{C}\right)$ can be seen in these figures also. Gelling temperature of Group A and Group B were closed to each other and from these values, Group A was found to be more suitable for foods in refrigerator conditions. The samples studied had a relatively sharp increase in delta value as the temperature decreases and rapid phase change was observed for both samples when viscosity became zero. Lower gelling temperature $\left(8.9^{\circ} \mathrm{C}\right)$ was measured in Group A compared $11.9^{\circ} \mathrm{C}$ in Group B. Determined gelling temperatures were found to be lower (in Group A) and higher (in Group B) when compared with the study of Kasankala et al., (2007). Those researchers reported $10.5^{\circ} \mathrm{C}$ gelling temperature for porcine skin gelatin gels in their study. These results showed that sea bream scale gelatin produced by using acetic acid is more suitable for industry with its $8.9^{\circ} \mathrm{C}$ gelling point and might be more useful for particular food applications that require gelling temperatures like other gelatins. All these results have some similarities with the study of Boran et al., (2010).

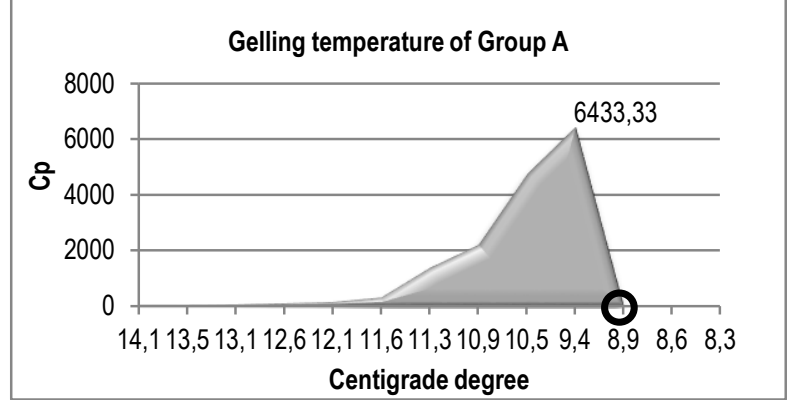

Figure 1. Gelling temperature value of Group A gelatin

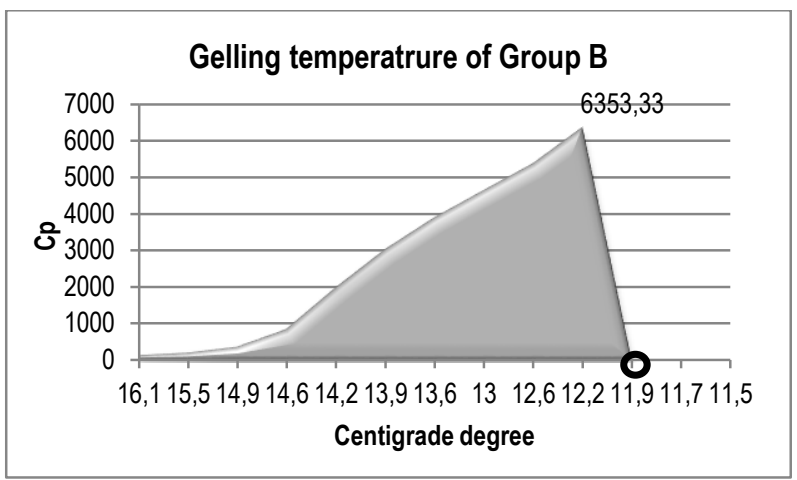

Figure 2. Gelling temperature value of Group B gelatin 


\section{Gel strength and mechanical properties}

Fish orginated gelatin is typically known to have a lower gel strength than mammalian gelatin. Gel strength (bloom value) is the most important functional properties that is directly related with the quality (Gilsen and Ross-Murphy 2000). While the values found in the study of Cho et al (2004) agreed with this statement, on the other hand in the study of Dincer et al., (2015) the gel strength of sea bass scale gelatin $(305 \mathrm{~g})$ was found to be higher than the findings of Cho et al., (2004) contradicts this statement. The part and species of the used fish were considered to be the sources of this difference. We could say that the statement of Gilsen and Ross-Morphy, (2000) may only be accepted for the gelatin obtained from cold-water species and especially fish skin gelatins. Gel strength is a function of complex interactions determined by the ratio of $\alpha$-chain and the amount of $\beta$-component and structure of gelatin is more stable when the imino acids(Hydroxy proline+ proline) content is higher(Gommez-Gullien et al., 2002). In another study, researchers investigate the imino acid contents of the fish scales and these imino acids were found higher in fish scales than in fish skin (Dincer et al., 2015; Cho et al., 2004). Gel strength of Group A and Group B are shown in Table 3. In both groups gel strengths were found to be higher than $300 \mathrm{~g}$. According to Gelatin Manufacturers Institute of America (GMIA)'s standards (GMIA, 2012), commercial gelatin gel strength should have gel strenght value between 100 and 300 $\mathrm{g}$ to used in the industrial sector. So in the current study obtained gelatins Bloom values were determined more than $300 \mathrm{~g}$ which can be considered in the range of "high-bloom gelatin" for the industry. In previous studies Bloom value range of aquatic gelatins varies between 0 and $270 \mathrm{~g}$ (Karim and Bhat, 2009). Moreover, Bloom values for bovine or porcine gelatin, which have gel strength values of $200-240 \mathrm{~g}$. And also in some studies gelatins of warm-water fish species have been reported to exhibit relatively high Bloom values, close to that of pork gelatin. Such high gel strength values can be seen only from the skins of warm-water fish such as tilapia (Zhou et al., 2006). Bloom values ranging from 128 to $273 \mathrm{~g}$ have been reported for tilapia gelatin (Zhou et al., 2006; Jamilah and Harvinder, 2002). In the current study, the Bloom value of gelatin was also found to be high (in Group A; 312.06 $8.47 \mathrm{~g}$ and in Group B; 317 . $36 \pm 9.18$ ), signifying that high quality gelatin was recovered in both groups. Textural profile values of the gels are also important in gelatin quality. In the current study determined texture profile analyses (TPA) results were higher than the results of the study done by Wangtueai and Noomhorm, (2009). In that study, researchers studied with lizard fish scales. TPA results of the extracted gelatins from lizard fish scales were as follows: hardness of $644 \pm 21.2$, chewiness of $616 \pm 64.07$, and springiness of $1.01 \pm 0.07$. Researchers also compared their results with bovine gelatins but determined values of bovine gelatin were also lower than sea bream scale gelatin values. Similiar results in comparisons were also seen in the study of Rahman and Al-Mahrouqi, (2009). In their study these researchers compared grouper skin gelatin and bovine-porcine mixed gelatin but in all groups of their study, determined results were lower than the values of current study. These comparisons show that, in the current study, high-quality fish scale gelatin was produced with a better textural profile. Also very similiar results were found in the study of Dincer et al., (2015) in sea bass scales. TPA results can be seen in Table 3.

Table 3. Gel strength and mechanical properties (TPA) of the gelatin groups

\begin{tabular}{llllllll}
\hline Gelatin & Gel strenght & \multicolumn{5}{c}{ Texture profile analyses } \\
\cline { 3 - 7 } Groups & $\mathbf{( g )}$ & Hardness $(\mathbf{g})$ & Adhesiveness & Springiness & Cohesiveness & Chewiness $\mathbf{( g )}$ & Resilience \\
\hline Group A & $312.06 \pm 8.47^{\mathrm{a}}$ & $3914.55 \pm 341.95^{\mathrm{a}}$ & $-23.83 \pm 9.50^{\mathrm{a}}$ & $0.98 \pm 0.02^{\mathrm{a}}$ & $0.83 \pm 0.02^{\mathrm{a}}$ & $3018.51 \pm 620.71^{\mathrm{a}}$ & $0.63 \pm 0.04^{\mathrm{a}}$ \\
Group B & $317.36 \pm 9.18^{\mathrm{a}}$ & $3779.57 \pm 508.48^{\mathrm{a}}$ & $-31.31 \pm 12.62^{\mathrm{a}}$ & $0.97 \pm 0.02^{\mathrm{a}}$ & $0.80 \pm 0.01^{\mathrm{b}}$ & $3047.98 \pm 422.73^{\mathrm{a}}$ & $0.65 \pm 0.02^{\mathrm{a}}$ \\
\hline
\end{tabular}

Data are expressed as mean \pm stdev, $(n=10)$

Different superscript letters in the same column indicate significant differences $(P<0.05)$

Group A; Sea bream scale gelatin obtained by acetic acid, Group B; Sea bream scale gelatin obtained by propionic acid.

Commercial gelatin is not colourless in solution but has colours varying from a very pale yellow to dark amber (Cole and Roberts, 1996). There can be no doubt that the colour attribute of gelatine has practical significance in that some $60 \%$ of world production is consumed by the confectionery industry (Yang et al., 2009). Furthermore, in the minds of most people the lack of colour is associated with purity, hence, pale colour is normally more desirable than darker colour. Manufacturers (Hoffmann, 1985) recognise the importance of gelatine colour. As mentioned in material section two different reference kits were used as a base in color measurements (B\&W) because of the transparency of the gels. Figure 3 denotes the results of White tile values and determined $L^{*}, a^{*}, b^{*}$ values were respectively;
$13.72 \pm 0.44,-8.62 \pm 0.26, \quad 2.37 \pm 0.22$ in Group $A$ and $12.40 \pm 1.36,-9.19 \pm 0.96,2.13 \pm 0.52$ in Group B. Figure 4 denotes the results of Black tile values. From the obatined results gelatins $L^{*}, a^{*}$ and $b^{*}$ values were determined as follows; $13.35 \pm 0.57,-8.79 \pm 0.27,1.54 \pm 0.31$ in Group $A$ and $12.57 \pm 0.98,-8.53 \pm 0.36,1.52 \pm 0.16$ in Group B. No statistical differences were determined between groups $(P<0.05)$. The difference in color among gelatins may occur due to the presence of pigment inherent in the material and depends on the raw material (Jongjareonrak et al., 2010). But observed results show that the different organic acids used did not affect the colour of the gelatin. In both groups colourless, transparent gelatin was obtained. 


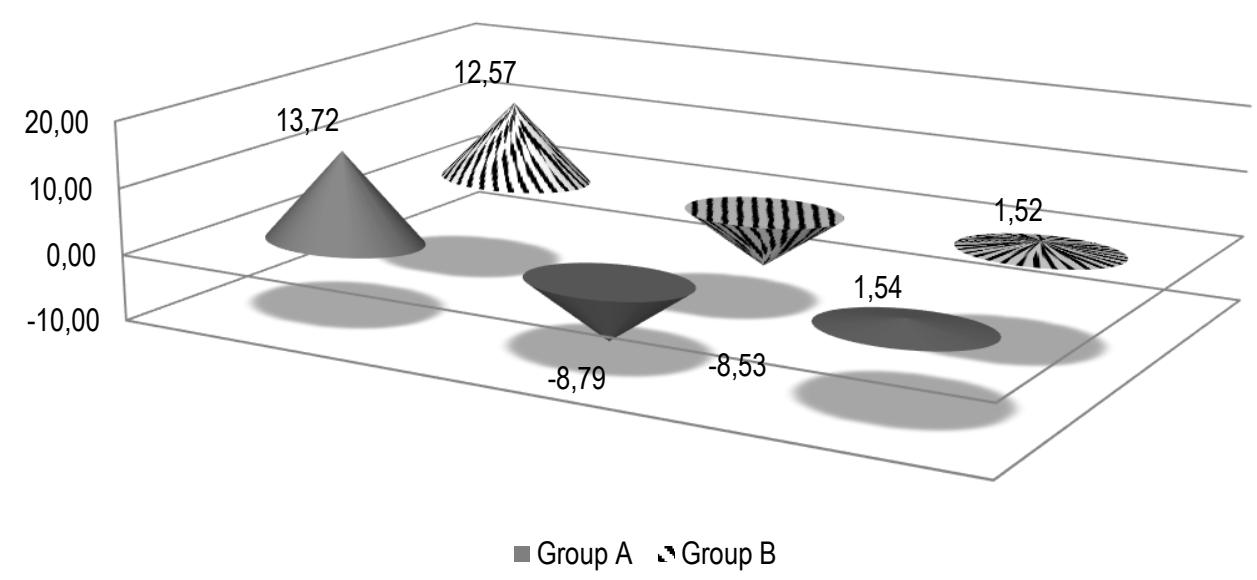

Figure 3. Colour measurement results over Tile White $(x=14.8, Y=21.2 ., Z=13.9)$

*Data were given $a s L^{*}, a^{*}$ and $b^{*}$ from left to right

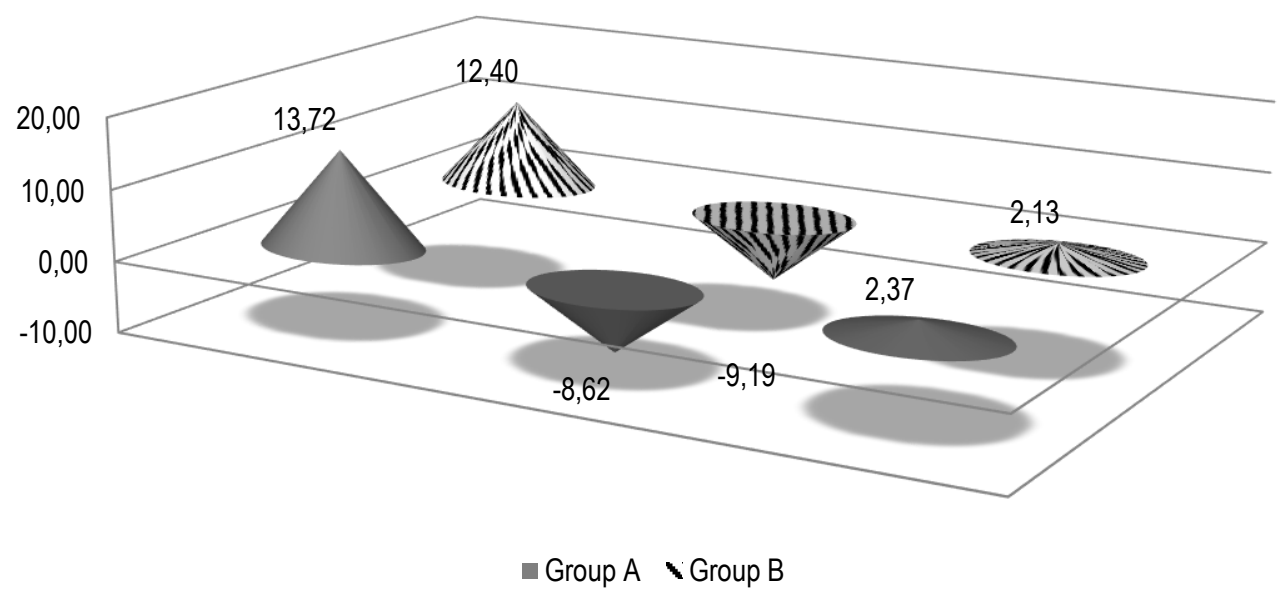

Figure 4. Colour measurement results over Tile Black $(x=14.5, Y=20.8, Z=15.0)$

*Data were given as $L^{*}, a^{*}$ and $b^{*}$ from left to right

\section{CONCLUSION}

From the results obtained, it is clear that fish scales have the potential to be an alternative source of collagen to mammalian collagen. Both acetic acid and propionic acid can be used in gelatin recovery. The main problem encountered in this stage was the production costs in laboratory conditions especially, the cost of EDTA and isobutyl alcohol that took much of the production cost. In future studies, alternative chemicals should be tried for deminerilasation and fat removing steps (like citric acid and less expensive alchols). We could

\section{REFERENCES}

AOAC. (2000). Official Methods of Analysis 17th ed., Association of Official Analytical Chemists, Arlington, USA.2200P

Arnesen, J.A. \& Gildberg, A. (2002). Preparation and characterisation of gelatine from the skin of harp seal (Phoca groendlandica). Bioresource Technology, 82, 191-194. DOI: 10.1016/S0960-8524(01)00164-X conclude that fish scale could be an alternative source of collagen for food, cosmetic and medical fields.

\section{ACKNOWLEDGMENTS}

This study was supported and funded by The Scientific and Technological Research Council of Turkey (TUBITAK) Project No. 1120952 and supported by Ege University Scientific Research Projects Coordination Unit (Project No. 2012-SÜF021). Used data are taken from the Msc Thesis project of the author Hulya (Sargin) Kalkan.

Boran, G. Mulvaney, M.S. \& Regenstein, J.M. (2010). Rheological properties of gelatin from silver carp skin compared to commercially available gelatins from different sources. Journal of Food Sciences, 75(8), 565-571. DOI: 10.1111/j.1750-3841.2010.01543.x 
Cho, S.M., Kwak, K.S., Park, D.C., Gu, Y.S., Ji, C.I., Jang, D.H., Lee, Y.B. \& Kim, S.B. (2004). Processing optimization and functional properties of gelatin from shark (Isurus oxyrinchus) cartilage. Food Hydrocolloid, 18 , 573-579. DOI:10.1016/j.foodhyd.2003.10.001

Cole, C. G. B. \& Roberts, J.J. (1996). Changes in the molecular composition of gelatine due to the manufacturing process and animal age, as shown by electrophoresis. Society of Leather Technologists and Chemists, 80, 136141.

Dincer, T., Akagündüz, Ö.Y. \& Sargın, H. (2013). Gelatin production by using sea bass (Dicentrarchus labrax) scales and determination of some functional properties of the prepared gelatin. Tubitak Project No 1120952 Final Report. 112 Pages.

Dincer, M.T, Ağçay Ö.A., Sargın H. \& Bayram, H. (2015). Functional properties of gelatin recovered from scales of farmed sea bass (Dicentrarchus labrax). Turkish Journal of Veterinary and Animal Sciences, 39, 102-109. DOI: 10.3906/vet-1406-68

Dinçer, M.T. Erdem, O.A., Kalkan, H. \& Üçok, M.Ç. (2016). Comparison of recovered carp scales (Cyprinus carpio) gelatin and commercial calf and pork skin gelatins. Ege Journal of Fisheries and Aquatic Sciences, 33(4), 335-341.

Gilsenan, P.M. \& Ross-Murphy, S.B. (2000). Rheological characterisation of gelatins from mammalian and marine sources. Food Hydrocolloids, 12 191-195. DOI: 10.1016/S0268-005X(99)00050-8

Gelatin Manufacturers Institute of America, (2012). Gelatin Handbook. Woburn, MA, USA: GMIA; 2012.

Gelatine Manufacturers of Europe, (2013). All About Gelatine. Brussels, Belgium.

Gommez-Guillien, M.C. \& Pillar, M. (2001). Extraction of Gelatin from Megrim (Lepidorhombus boscii) skins with several organic acids. Journal of Food Science, 66(2), 213 - 216. DOI: 10.1016/S0268-005X(01)00035-2

Gomez-Guillen C., Turnay, J., Fernandez-Diaz, M.D., Lizarbe, M.A. \& Montero, P. (2002). Structural and physical properties of gelatin extracted from different marine species: a comparative study. Food Hydrocolloids, 16 25-34. DOI:10.1016/S0268-005X(01)00035-2

Grossman, S., Bergman, M. (1992). Process for the production of gelatin from fish skins. U. S. patent $5,093,474$

Gudmundsson, M. \& Hafsteinsson, H. (1997). Gelatin from cod skins as affected by chemical treatments. Journal of Food Science, 62(1), 37-39.

Hoffmann, P., 1985. Deutsche-Milchwirtschaft. 35, 269.

Jamilah, B., Harvinder, K.G. (2002). Properties of gelatins from skins of fish black tilapia (Oreochromis mossambicus) and red tilapia (Oreochromis nilotica). Food Chemistry, 77, 81-84. DOl:10.1016/S0308-8146(01)00328-4

Jongjareonrak, A., Rawdkuen, S., Chaijan, M., Benjakul, S., Osako, K. \& Tanaka, M. (2010). Chemical compositions and characterisation of skin gelatin from farmed giant catfish (Pangasianodon gigas). LWT Food Science and Technology, 43: 161-165. DOI: 10.1016/j.Iwt.2009.06.012

Karim, A.A. \& Bhat, R. (2009). Review fish gelatin: properties, challenges, and prospects as an alternative to mammalian gelatins. Food Hydrocolloids. 23, 563-576. DOI: 10.1016/j.foodhyd.2008.07.002

Kasankala, L.M., Xue Y., Weilong Y., Hong S.D. \& He, Q. (2007). Optimization of gelatine extraction from grass carp (Catenopharyngodon idella) fish skin by response surface methodology. Bioresources Technology, 98, 33383343. DOI: 10.1016/j.biortech.2006.03.019

Kim, J.S. \& Cho, S.Y. (1996). Screening for raw material of 1 modified gelatin in marine animal skins caught in coastal offshore water in Korea. Agricultural Chemistry and Biotechnology, 39, 134- 139.

Kimura, S., Miyauchi, Y. \& Uchida, N. (1991). Scale and bone type I collagens of carp (Cyprinus carpio). Comparative Biochemistry and Physiology, 99B, 473-476. DOI: 10.1016/0305-0491(91)90073-M

Kinsella, J. E. (1977). Functional properties of protein: possible relationships between structure and function in foams. Journal Food Chemistry, 7, 273288.
Leuenberger, B.H. (1991). Investigation of viscosity and gelation properties of different mammalian and fish gelatins. Food Hydrocolloids, 5, 353-361.

Merrill, A.L. \& Watt, B.K. (1993). Energy value of foods, basis and derivation (P. 2). Agriculture research service. United States Department of Agriculture. Agriculture handbook, 74 .

Montero P. \& Gomez-Guillen M.C. (2000). Extracting Conditionss for Megrim (Lepidorhombus boscii) Skin Collagen Affect Functional Properties of the Resulting Gelatin Journal of Food Science, 65(3), 434-438.

Muyong, J.H., Cole, C.G.B. \& Duodu, K.G. (2004). Fourier transform infrared (FTIR) spectroscopic study of acid soluble collagen and gelatin from skins and bones of young and adult Nile perch (Lates niloticus). Food Chemistry, 86, 325-332. DOI: 10.1016/j.foodchem.2003.09.038

Nagai, T., Izumi, M. \& Ishii, M. (2004). Fish scale collagen. Preparation and partial characterization. International Journal of Food Science and Technology. 39, 239-244. DOI: 10.1111/j.1365-2621.2004.00777.x

Nomura, Y., Sakai, H., Ishii, Y. \& Shirai, K. (1996). Preparation and some properties of type I collagen from fish scales. Bioscience Biotechnology and Biochemistry, 60, 2092-2094. DOI: 10.1271/bbb.60.2092

Norland, R.E. (1990). Fish gelatin. In: Advances in fi sheries technology and biotechnology for increased profi tability. Voight, M.N., Botta, J.K.(Ed) Technical Publication Lancaster. pp.325-333.

Osborne, R., Voigt, M.N. \& Hall, D.E. (1990). Utilization of lumpfish (Cyclopterus lumpus) carcasses for the production of gelatin. In: Advances in fisheries technology and biotechnology for increased profitability. Voight, M. N., Botta, J. K(Ed). Technical Publication, Lancaster. pp. 143153.

Rahman, M. S., Al-Saidi, G. S. \& Guizani, M. (2008). Thermal characterisation of gelatin extracted from yellowfin tuna skin and commercial mammalian gelatin. Food Chemistry, 108, 472-481. DOI: 10.1016/j.foodchem.2007.10.079

Sankar, S., Sekar, S., Mohan, R., Rani, S., Sundaraseelan, J. \& Sastry, T.P. (2008). Preparation and partial characterization of collagen sheet from fish (Lates calcarifer) scales. International Journal of Biological Macromolecules, 42, 6-9. DOI: 10.1016/j.ijbiomac.2007.08.003

Sathe, S.K., Deshpande, S.S. \& Salunkhe, D.K. (1982). Functional properties of lupin seed (Supinus mutabilis) proteins and protein concentrates. Journal of Food Science, 7, 191-197.

Stainsby, G. (1987). Gelatin gels. In: Pearson AM, Dutson TR, Bailey AJ, (Ed). Advances in meat research. Vol. 4. Collagen as a food. New York: Van Nostrand Reinhold Company Inc. pp 209-222.

Schubring, R. (2003). Colour measurement for the determination of the freshness of fish. In: J.B. Luten, J. Oehlenschlager and G. Olafsdottir, (Ed), Quality of fish from catch to consumer: Labelling, monitoring and traceability ( $p p$ 251-263) The Netherlands: Wageningen Academic Publishers

Wangtueai, S. \& Noomhorm, A. (2009). Processing optimization and characterization of gelatin from lizardfish (Saurida spp.) scales. LWT Food Science and Technology, 42, 825-834. DOI:10.1016/j.Iwt.2008.11.014

Yang, H., Wang, Y., Jiang, M., Oh, J.H., Herring, J. \& Zhou, P. (2007). Step optimization of the extraction and subsequent physical properties of channel catfish (Ictalurus punctatus) skin gelatin. Journal of Food Science, 72, 188 - 195. DOI: 10.1111/j.1750-3841.2007.00319.x

Yang, J.I., Liang, W.S., Chow, C.J. \& Siebert, K.J. (2009). Process for production of tilapia retorted skin gelatin hydrolysates with optimized antioxidative properties. Process Biochemistry, 44(10), 1152-1157. DOI:10.1016/j.procbio.2009.06.013

Zhou, P. \& Regenstein, J.M. (2004). Optimization of extraction conditions for pollock skin gelatin. Journal of Food Science, 69(5),393-397. DOI:10.1111/j.1750-3841.2006.00065.x

Zhou, P. Mulvaney, S.J., \& Regenstein, J.M. (2006). Properties of Alaska Pollock skin gelatin: A comparison with Tilapia and pork skin gelatins. Journal of Food Science, 71, 313-321. DOI:10.1111/j.1365-2621.2004.tb10704.x 